\title{
BASAL CELL CARCINOMA WITH ECCRINE DIFFERENTIATION: A RARE ENTITY
}

\author{
Divvya B ${ }^{1}$, Rehana Tippoo², P. Viswanathan³ , B. Krishnaswamy ${ }^{4}$, A. Anvar Ali ${ }^{5}$
}

\section{HOW TO CITE THIS ARTICLE:}

Divvya B, Rehana Tippoo, P. Viswanathan, B. Krishnaswamy, A. Anvar Ali. "Basal Cell Carcinoma with Eccrine Differentiation: A Rare Entity". Journal of Evolution of Medical and Dental Sciences 2014; Vol. 3, Issue 21, May 26; Page: 5905-5910, DOI: 10.14260/jemds/2014/2681

ABSTRACT: Basal cell carcinoma preferentially occurs in the face where the surgical excision with adequate margin is curative. Sometimes basal cell carcinoma is also reported rarely in other sites especially associated with basal cell carcinoma syndrome. The histological variants are Nodular basal cell carcinoma, Keratotic basal cell carcinoma, Adenoid basal cell carcinoma, Basal cell carcinoma with sebaceous differentiation. Of these variants, Basal cell carcinoma with eccrine differentiation is practically very rare.

KEYWORDS: Basal cell carcinoma, Eccrine differentiation, Basal cell carcinoma Unusual site.

CLINICAL PRESENTATION: A 65 year old female patient presented with a slowly expanding nonhealing ulcer in the calf region of left leg for the past 1 year. There was no other constitutional syndrome. Following the diagnostic biopsy procedure the entire lesion was excised with wide surgical clearance and submitted for histopathological examination.

MACROSCOPY: A single skin covered tissue measuring $8 \mathrm{~cm}$ in diameter with a central grey white lesion measuring $3.5 \times 2.5 \mathrm{~cm}$. Borders of the lesion were raised. Samples were taken. Surgical margins and base were also sampled.

MICROSCOPY: The histological slides were studied along with the detailed clinical history and surgical findings.

Sections revealed a cellular tumor, where the tumor cells were distributed as nodules of varying sizes and dimensions, diffusely infiltrating the deeper dermis. The nodules were composed of two types of cells, basaloid cells with hyperchromatic nuclei showing peripheral palisading and cells with relatively pale cytoplasm located at the centre of the nodule. Eccrine differentiation and vague ductular differentiation were observed. Mitotic figures including the ones with peculiar starburst appearance were seen. Resected margins and base were free from tumor involvement.

The final histological diagnosis is consistent with the diagnosis of Basal cell carcinoma with eccrine differentiation.

DISCUSSION: Basal cell carcinoma is a locally malignant tumor with a high degree of recurrence rate. The traditional site is exclusively on hair-bearing skin, especially on the face, but rarely seen in other areas also such as palms or on the soles. ${ }^{1}$

Basal cell carcinoma can be seen in association with nevoid basal cell carcinoma syndrome, linear unilateral basal cell nevus, and Bazex syndrome. ${ }^{1}$ 
The histological characteristics are predominant basal cell type, peripheral palisading of lesional cell nuclei, a specialized stroma, and clefting artefact between the epithelium and the stroma. In addition, there are variable degrees of cytologic atypia and mitotic activity.

The histological variants are Nodular basal cell carcinoma, Basal cell carcinoma, solid type with cystic degeneration, Infiltrative basal cell carcinoma, Adenoid basal cell carcinoma, Micronodular basal cell carcinoma, Pigmented basal cell carcinoma, Keratotic basal cell carcinoma, Basal cell carcinoma with sebaceous differentiation and Fibroepithelioma of Pinkus (fibroepithelial basal cell carcinoma). ${ }^{1}$

Eccrine differentiation was first reported in 1969 and was called as eccrine epithelioma, where vague ductular differentiation was also seen. Other tumors with eccrine differentiation are malignant cylindroma, malignant eccrine poroma, malignant eccrine spiradenoma, malignant nodular hidradenoma and malignant chondroid syringoma.

However the Basal cell carcinoma also can reveal eccrine differentiation rarely ${ }^{2}$ especially in Adenoid basal cell carcinoma variation.

BCC with sweat duct differentiation typically seen in nodular BCC in $1 \%$ of cases in our experience is otherwise typical eccrine, and sometimes, apocrine differentiation ${ }^{3,4}$ whereby tubules lined by the cuboidal epithelium with an internal eosinophilic cuticle are centrally disposed in otherwise typical basaloid tumor cell aggregates. The internal eosinophilic cuticle decorates with immunohistochemical stains for carcinoembryonic antigen and epithelial membrane antigen. ${ }^{3,5}$

In the present case, varying degrees of eccrine and ductular differentiation is seen. Mitotic figures with a "starburst" appearance similar to those seen in basal cell carcinoma are also observed. Similarly, as in the classical basal cell carcinoma the cells peripheral to the tumor nodular are distributed perpendicular to the stroma and the cells in the centre are paler compared to the hyperchromatic peripheral cells.

The Eccrine differentiation in basal cell carcinoma indicates the common ancestry of basal cell origin which can be omnipotent to some extent in differentiation.

Basal cells can also show sebaceous and follicular differentiation.

In the present patient, following the excision, the ulcer was grafted with autologus skin graft. The lady was discharged with a good graft take. Long term follow up is planned.

\section{EQUIPMENT USED:}

Nikon Coolpix-8400

$\mathrm{x}$-denotes the power of objective

Stain used - (H \& E)

\section{REFERENCES:}

1. Walter F Lever. Histopathology of the skin: In: David E Elder, Rosalie Elenitsas, Bernett L. Johnson, George F. Murphy eds. Lever's Histopathology of the skin., Lipincott Williams \& Wilkins, Ninth edn, 2004: 1079 - 80.

2. Sanchez NP, Winkelmann RK. Basal cell tumor with eccrine differentiation (eccrine epithelioma). J Am Acad Dermatol 6:514-518, 1982.

3. Hanke CW, Temofeew RK. Basal cell carcinoma with eccrine differentiation (eccrineepithelioma). J Dermatol Surg Oncol 1986;12:820-824 


\section{CASE REPORT}

4. Misago N, Satoh T, Narisawa Y. Basal cell carcinoma with ductal and glandular differentiation: a clinico-pathological and immunohistochemical study of 10 cases. Eur J Dermatol 2004;14: 383-387.

5. Kato N, Ueno H. Infundibulocystic basal cell carcinoma. Am J Dermatopathol 1993;15: 265-267.

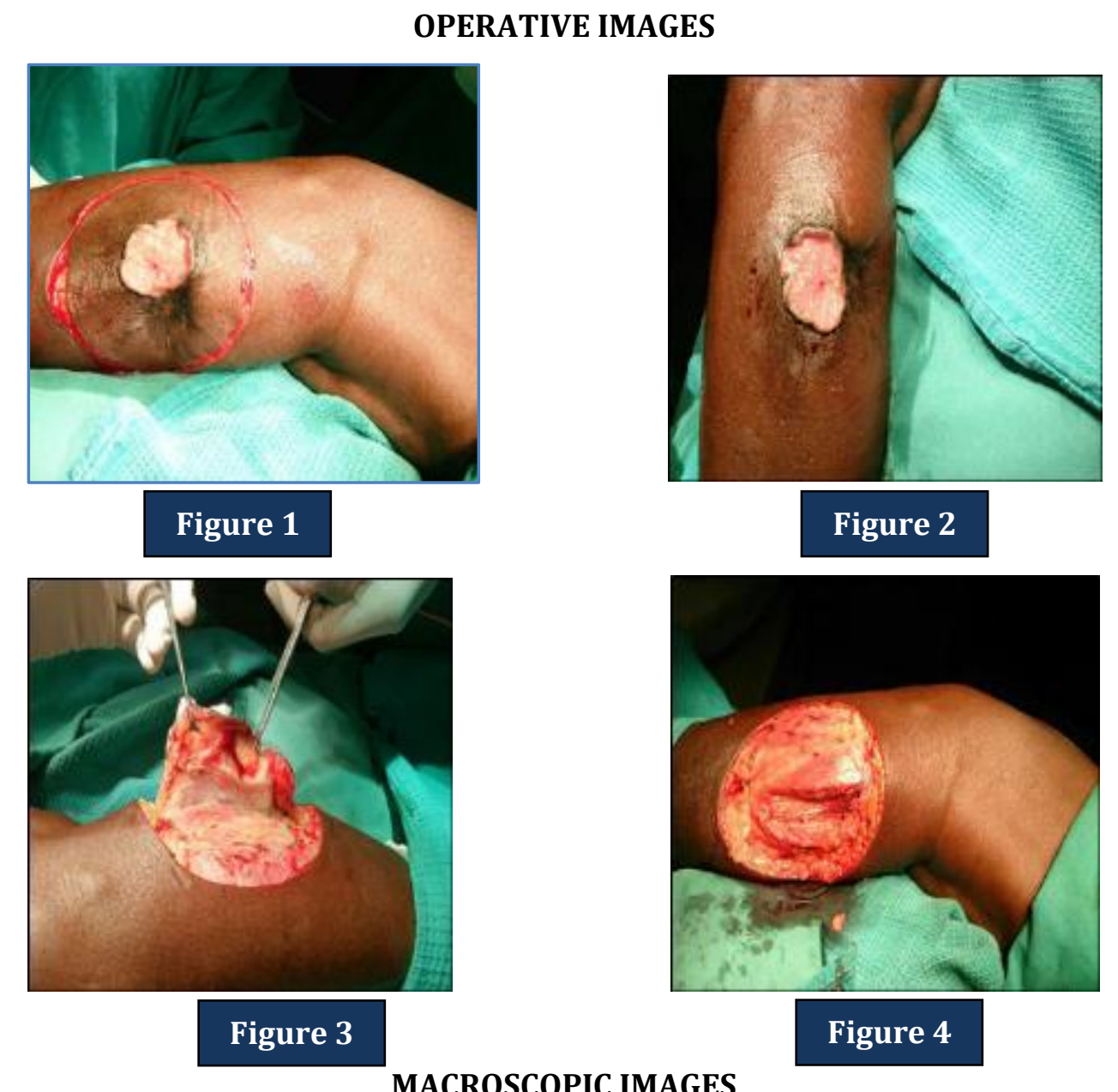

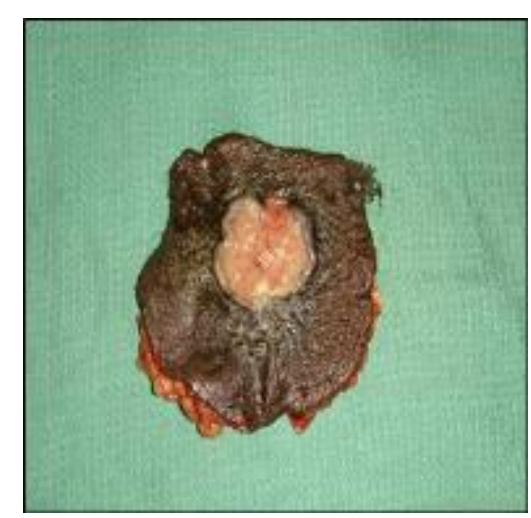

Figure 5: Fresh Specimen

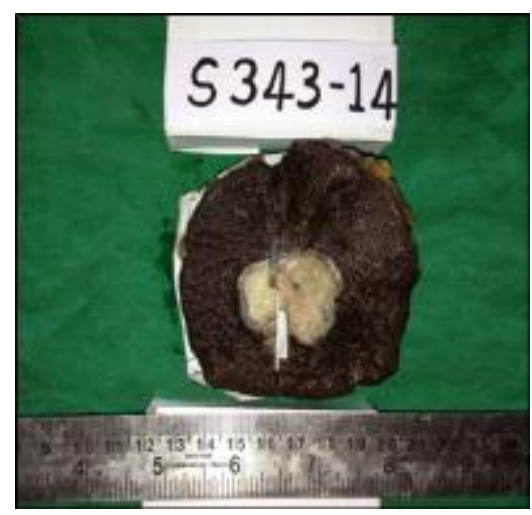

Figure 6: Formalin Fixed Specimen 


\section{CASE REPORT}

Cut section of formalin fixed specimen:

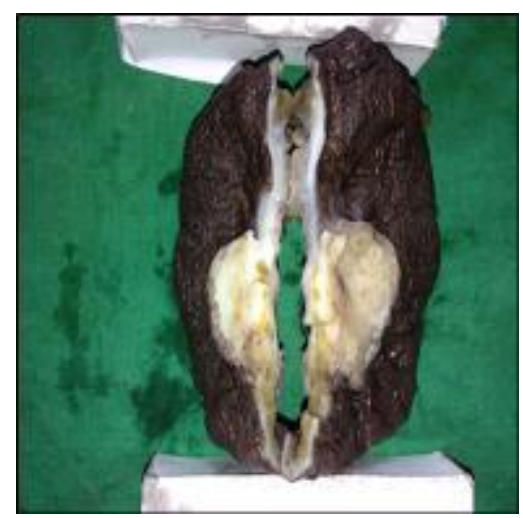

Figure 7

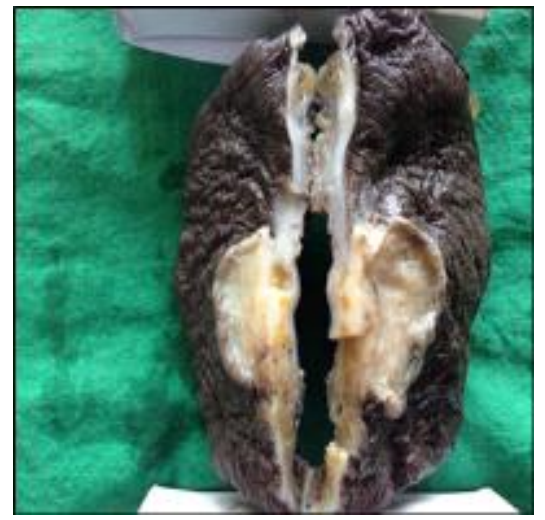

Figure 8

MICROSCOPIC IMAGES

Tumor nests involving deeper stromal tissue:

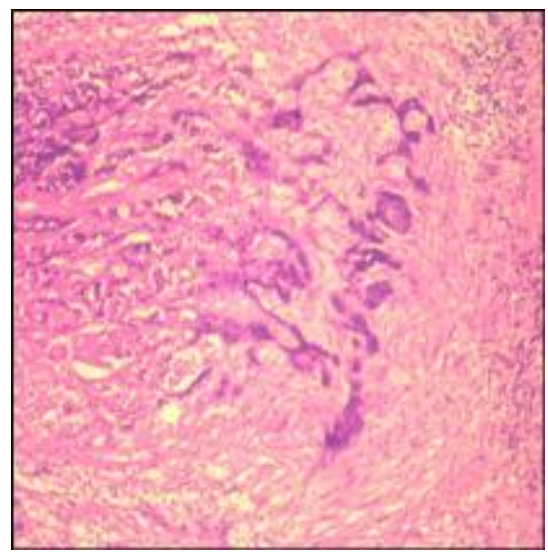

Figure 9: H \& E stained 4 x

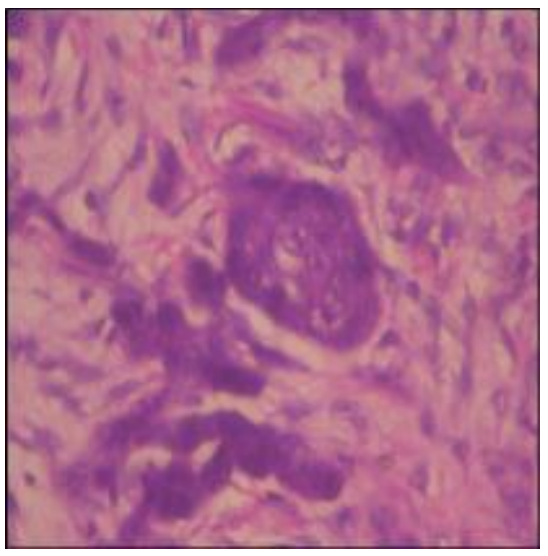

Figure 10: H \& E stained $40 \mathrm{x}$

Tumor originating from basal layer of epidermis is seen as nests:

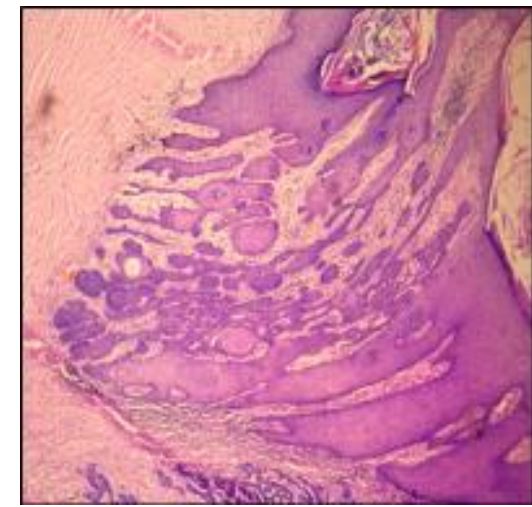

Figure 11: H \& E stained $4 x$

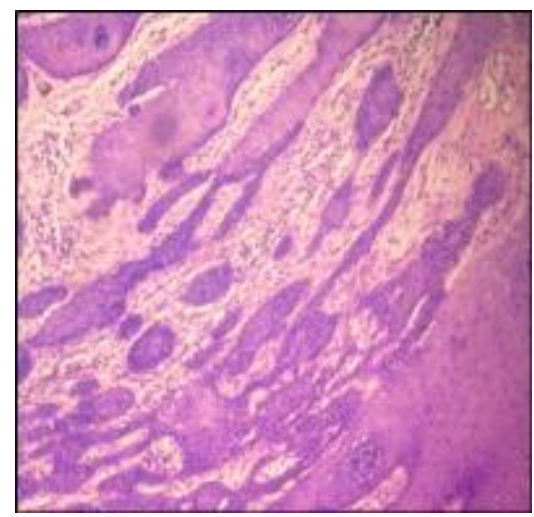

Figure 12: H \& E stained $10 \mathrm{x}$ 


\section{CASE REPORT}

Tumor cells seen as nodules of varying dimension and size appearing like a piece of jigsaw puzzle. They tend to form vague ductular differentiation.

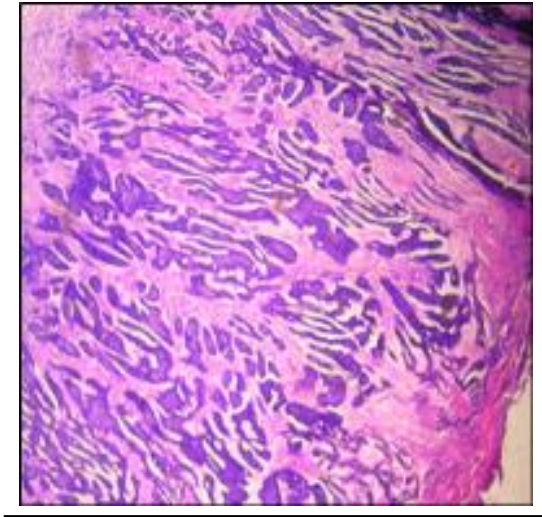

Figure 13: H \& E stained $4 \mathrm{x}$

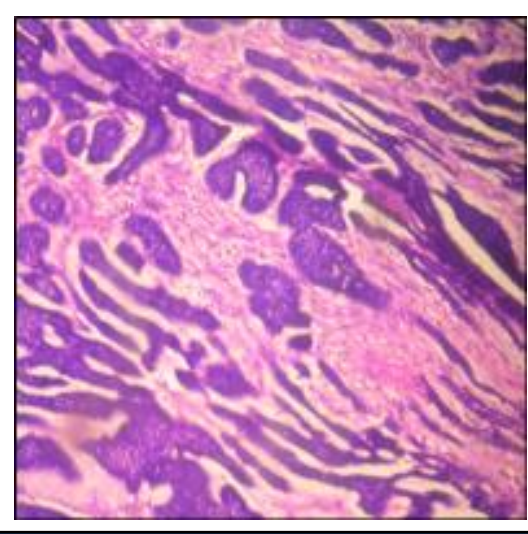

Figure 14: H \& E stained $10 \mathrm{x}$

Eccrine differentiation Starburst mitotic figure.

The tumor nodules contain two types of cells, peripheral hyperchromatic cells and relatively pale cells at the centre.
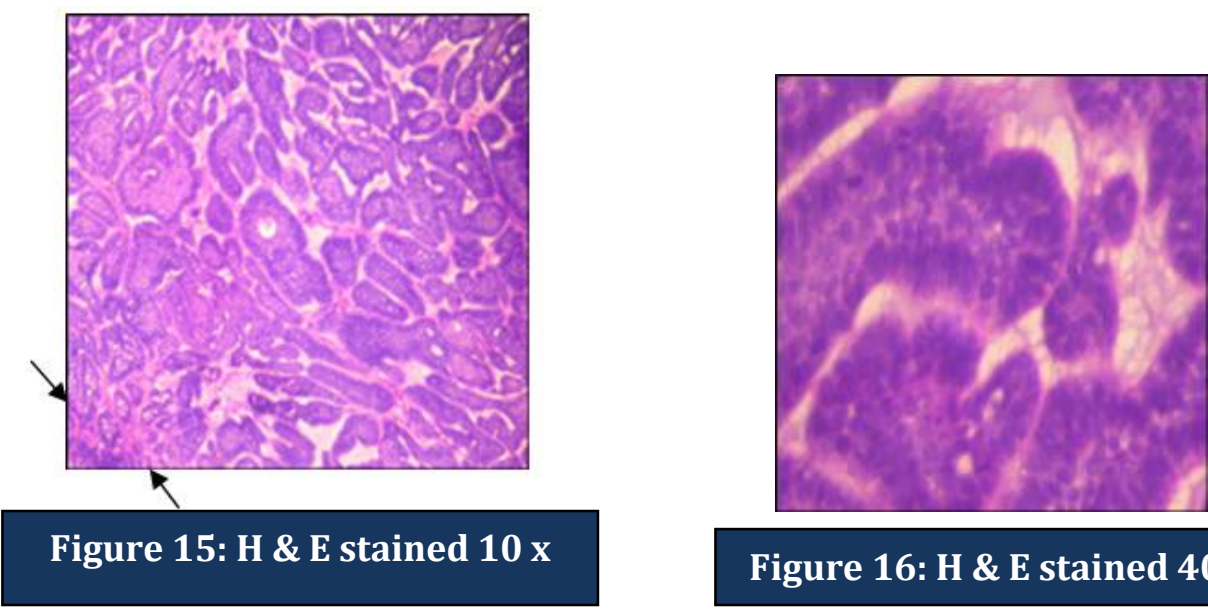

\section{Figure 16: H \& E stained $40 \mathrm{x}$}

Horn Cyst: Tumor Nodule showing peripheral palisading of nucleus and occasional characteristic starburst mitotic figure.

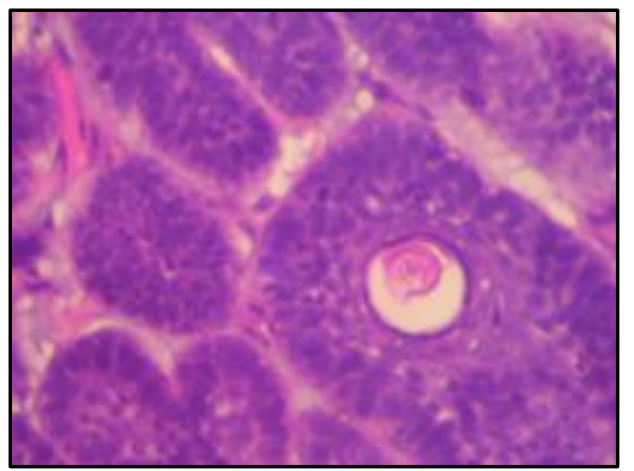

Figure 17: H \& E stained $40 x$ 


\section{CASE REPORT}

\section{AUTHORS:}

1. Divvya B.

2. Rehana Tippo

3. P. Viswanathan

4. B. Krishnaswamy

5. A. Anvar Ali

\section{PARTICULARS OF CONTRIBUTORS:}

1. II ${ }^{\text {nd }}$ Year Post Graduate, Department of Pathology, Rajah Muthiah Medical College, Annamalai University.

2. Professor, Department of Pathology, Rajah Muthiah Medical College, Annamalai University.

3. Professor, Department of Pathology, Rajah Muthiah Medical College, Annamalai University.

4. Professor, Department of Pathology, Rajah Muthiah Medical College, Annamalai University.
5. Professor, Department of Surgery, Rajah Muthiah Medical College, Annamalai University.

\section{NAME ADDRESS EMAIL ID OF THE CORRESPONDING AUTHOR:}

Dr. P. Viswanathan,

Professor, Department of Pathology,

Faculty of Medicine,

Rajah Muthiah Medical College,

Annamalai University,

Chidambaram-608002,

Tamilnadu, India.

Email: drviswanathan2013@gmail.com

Date of Submission: 06/05/2014.

Date of Peer Review: 07/05/2014.

Date of Acceptance: 15/05/2014.

Date of Publishing: 26/05/2014. 